\title{
National Corporate Governance Codes and IT Governance Transparency in Annual Reports
}

\author{
Steven De Haes, University of Antwerp-Antwerp Management School, Antwerp, Belgium \\ Tim Huygh, University of Antwerp, Antwerp, Belgium \\ Anant Joshi, Maastricht University, Maastricht, Netherlands \\ Laura Caluwe, University of Antwerp, Antwerp, Belgium
}

\begin{abstract}
IT governance is concerned with the oversight of IT assets, their contribution to business value and the mitigation of IT-related risks. Emerging research calls for more board level engagement in IT governance and identifies profound consequences for digitized organizations in case the board is not involved. Against this context, this article analyses how corporate governance codes are guiding boards to provide transparency on how they treat IT governance. The findings show that only the South African corporate governance code, King III, contains a significant amount of IT (governance)-related content. As a second objective, this article builds on these findings by providing an exploratory insight in the contemporary state of IT governance transparency in Belgian and South African companies. This way, the influence of the national corporate governance code on IT governance transparency is explored. The authors' findings show that South African firms tend to be more concerned with IT governance transparency in their annual reports than Belgian firms, given a comparable IT strategic role and ownership structure. Accordingly, the case is made for including more IT (governance)related guidance in national corporate governance codes, as this might enable companies to be more transparent about their IT governance.
\end{abstract}

\section{KEYWORDS}

Annual Report, Business Value, Corporate Governance Code, IT Governance Transparency

\section{INTRODUCTION}

IT governance is concerned with optimizing the business value generated through IT assets, while simultaneously mitigating IT-related risks (Weill \& Ross, 2004). Over time, IT governance gained momentum due to more companies becoming critically dependent on IT for their operational and strategic business activities (De Haes \& Van Grembergen, 2015; Nolan \& McFarlan, 2005). The potential benefits of IT governance are well-known by now. Weill \& Ross $(2004$, p. 4$)$ state that “... effective IT governance is the single most important predictor of the value an organization generates 
from IT..." Many studies have surfaced that identified mechanisms for IT governance (De Haes \& Van Grembergen, 2009; Huang, Zmud, \& Price, 2010; Prasad, Green, \& Heales, 2012; Weill \& Ross, 2004). Due to a direct link between corporate governance and IT governance (De Haes \& Van Grembergen, 2015; IT Governance Institute (ITGI), 2003; Weill \& Ross, 2004), many corporate governance mechanisms are translated into the IT governance domain. An important issue in corporate governance literature is transparency, or disclosure (Augustine, 2012; Millar, Eldomiaty, Choi, \& Hilton, 2005; Morris, Pham, \& Gray, 2011). However, the issue of IT governance transparency/ disclosure, which is about providing stakeholders with information about the way the organization is governing its IT assets, has received little attention in academic research (Joshi, Bollen, \& Hassink, 2013). Joshi et al. (2013) proposed a framework to assess the level of IT governance disclosure, together with a call for additional empirical research to contribute to the under-researched topic of IT governance transparency. In response, this study explores the influence of the national corporate governance code on a firm's IT governance transparency. Therefore, a selection of national corporate governance codes is analyzed with respect to the included IT (governance)-related content. Building on these findings, the contemporary state of IT governance transparency in Belgian and South African companies are compared by means of their annual reports. Indeed, there could be potential variations in IT governance disclosure due to variations in the national corporate governance code. Differences in IT governance transparency between Belgian and South African companies can be expected, as the South African corporate governance code contains a significant amount of IT (governance)-related guidance, while the Belgian code does not. While controlling for the IT strategic role (i.e. financial services organizations) and firm ownership structure (i.e. listed companies), the investigation of the effect of the national corporate governance code on a firm's tendency to disclose on its IT governance is an important contribution to the body of knowledge about IT governance transparency.

Following the problem statement and research objectives discussed in the previous paragraph, the following research questions are put forward:

RQ1: What IT (governance)-related guidelines are contained in national corporate governance codes and what differences can be observed between various corporate governance codes?

RQ2: To what extent does the national corporate governance code influence the level of IT governance disclosure of a firm?

From the second research question, the following proposition was derived for guiding the empirical part: Firms that are submitting their annual report based on a corporate governance code that contains more (non-committal) IT (governance)-related guidance disclose more on their IT governance compared to firms that are submitting their annual report based on a corporate governance code that contains less IT (governance)-related guidance. This proposition has important consequences for the sampling criteria, which will be discussed in the 'research methodology' section. It should be noted that this proposition serves a more directive purpose, rather than conclusive, as the small sample size $(\mathrm{N}=20)$ used in this research does not allow for formal statistical significance testing. Nevertheless, we aim to provide an in-depth qualitative discussion of the issues at hand.

The remainder of this paper is structured as follows. The second section provides a theoretical background to this research by discussing the concepts of corporate governance, corporate governance code, IT governance and IT governance transparency, and a short discussion of the IT governance transparency framework by Joshi et al. (2013), which will be used for our exploratory empirical research by serving as the measurement instrument for the IT governance disclosure construct. The third section contains the research methodology. The fourth section presents the results of the empirical research. The fifth section presents the main conclusions and the research implications (for theory and practice). Finally, the sixth section contains the limitations of this research, as well as opportunities for future research. 


\section{THEORETICAL BACKGROUND}

\subsection{Corporate Governance and Corporate Governance Codes}

According to OECD (2015), "Corporate governance involves a set of relationships between a company's management, its board, its shareholders and other stakeholders. Corporate governance also provides the structure through which the objectives of the company are set, and the means of attaining those objectives and monitoring performance are determined." Corporate governance reflects how decision rights and responsibilities are distributed among stakeholders in the organization, and the rules and procedures for organizational decision-making (Lin, 2011). Corporate governance is concerned with the mitigation of potential conflicts of interest between all stakeholders of an organization (Goergen, 2012). This is especially the case when there is a separation of ownership and management, leading to a principal-agent issue as described in agency theory (Eisenhardt, 1989; Uhlaner, Wright, $\&$ Huse, 2007). Corporate governance can be implemented in an organization using a set of corporate governance mechanisms, consisting of structures, processes, and relations (Shailer, 2004).

Corporate governance received worldwide attention following a series of scandals, most of which involved major accounting fraud. The Enron and WorldCom scandals were the major drivers for passing the Sarbanes-Oxley (SOX) Act in 2002 as an attempt by the US government to legislate a set of good practices for corporate governance (Ailon, 2011). The main purpose of the act is strengthening corporate accountability to protect investors. With the introduction of Sarbanes-Oxley, good corporate governance and ethical business practices became the law, forcing public companies to enhance internal checks and balances (Damianides, 2005). As opposed to SOX, the practices contained in most national corporate governance codes follow the "comply or explain"-principle. The underlying idea of this principle, traceable all the way back to the 1992 UK Cadbury report, is a corporate governance disclosure obligation (as opposed to a compliance obligation). By rejecting the "one size fits all" approach, it allows firms to publicly explain the reasons for not complying with a certain corporate governance principle, acknowledging that different contexts/contingencies might require different governance approaches. The disclosure should be more than just a statement of compliance or non-compliance, as it should also contain a reasoned explanation for each instance of non-compliance. This way, a market sanction instead of a legal sanction is anticipated in the case of inappropriate governance (MacNeil \& Li, 2006). The "comply or explain"-principle ultimately means that the practices and guidelines contained in these corporate governance codes are non-committal.

The OECD introduced their "principles of corporate governance" for the first time in 1999, and published updated versions in 2004 and 2015. Many OECD and non-OECD countries used the OECD principles as a basis to build their own national corporate governance codes. Some countries even have multiple corporate governance codes (e.g. a separate code for listed and non-listed companies). The 2015 'G20-OECD principles of corporate governance' document contains six main chapters, of which the fifth is called "Disclosure and transparency". The main underlying principle for this chapter is: "The corporate governance framework should ensure that timely and accurate disclosure is made on all material matters regarding the corporation, including the financial situation, performance, ownership, and governance of the company..." (OECD, 2015, p. 37). This principle hence directly mentions the need for transparency about a firm's governance. OECD recognizes that laws are often only stipulating minimum disclosure requirements and that firms are therefore often voluntary disclosing additional information in response to market demand. The principle states that all "material matters" should be disclosed, which can be defined as "... information that a reasonable investor would consider important in making an investment or voting decision..." (OECD, 2015, p. 37). According to OECD, this enables 'market-based monitoring' of companies. The disclosure should include, but not be limited to, material information on (OECD, 2015, pp. 38-42):

- The financial and operating results of the company;

- Company objectives and non-financial information; 
- Major share ownership, including beneficial owners, and voting rights;

- Remuneration of members of the board and key executives;

- Information about board members, including their qualifications, the selection process, other company directorships and whether they are regarded as independent by the board;

- Related party transactions;

- Foreseeable risk factors;

- Issues regarding employees and other stakeholders;

- Governance structures and policies, including the content of any corporate governance code or policy and the process by which it is implemented.

Although directly mentioning the need for disclosure about "company objectives and nonfinancial information" (OECD, 2015, pp. 38-39), the OECD principles do not specifically mention IT (governance)-related information as part of non-financial information. Besides discussing the contents of disclosure, the 'disclosure and transparency' chapter also explicitly mentions the need for efficient disclosure channels. It is specifically stated that the company website provides an excellent way to disclose material company information. It should be noted that the other main chapters of the ' $\mathrm{G} 20$ / OECD principles of corporate governance' document do not contain any specific directions regarding IT governance, which also explains why there is no specific attention for IT (governance)-related disclosure in the 'disclosure and transparency' chapter. Nevertheless, it is the premise of this study that including IT (governance)-related content in corporate governance codes and guidelines will assist organizational decision-makers in their attempts at being transparent about their IT governance.

\subsection{IT Governance and IT Governance Transparency}

IT governance is an integral part of corporate governance (De Haes \& Van Grembergen, 2015), considering IT governance exists in the realm of overall corporate governance (Weill \& Ross, 2004). Van Grembergen \& De Haes (2009, p. 3) define the concept as “....an integral part of corporate governance and addresses the definition and implementation of processes, structures and relational mechanisms in the organization that enable both business and IT people to execute their responsibilities in support of business/IT alignment and the creation of business value from IT-enabled business investments..." Over time, IT governance gained momentum due to more companies becoming critically dependent on IT for their operational and strategic business activities (De Haes \& Van Grembergen, 2015; Nolan \& McFarlan, 2005). The above-mentioned definition by Van Grembergen \& De Haes (op. cit.) clearly indicates that IT governance is an integral part of corporate governance, requiring involvement of the board. Due to this direct link between both concepts, many of the issues that are discussed regarding corporate governance also apply to IT governance (Heart, Maoz, \& Pliskin, 2010; Mähring, 2006; Raghupathi, 2007). Drawing on the ideas of corporate governance, IT governance can be implemented using structures, processes, and relational mechanisms (De Haes \& Van Grembergen, 2009; Peterson, 2004; Weill \& Ross, 2004). In the IT governance body of knowledge, many different mechanisms are reported, such as strategy committees, steering committees, a portfolio management process, etc. (De Haes \& Van Grembergen, 2009; Huang et al., 2010; Prasad et al., 2012; Weill \& Ross, 2004). An important issue in corporate governance literature is transparency (Augustine, 2012; Millar et al., 2005; Morris et al., 2011). However, the associated but distinct issue of IT governance transparency, which is about providing stakeholders with information about the way the organization is governing its IT assets, has received little attention to date in academic research (Joshi et al., 2013).

Since disclosure about corporate governance is essential for organizations that are seeking for investors, and IT governance is considered to be an integral part of overall corporate governance, IT governance disclosure should also be considered by organizations. The importance of transparency about IT governance is mentioned in literature (Raghupathi, 2007), but is to this date vastly underresearched compared to disclosure about overall corporate governance (Joshi et al., 2013). Indeed, 
IT governance transparency is a separate issue from corporate governance transparency in general as it specifically addresses the disclosure on the governance of IT. IT governance transparency can be defined as "...the ability of firms to provide adequate and relevant IT governance information in a timely and effective manner to their stakeholders, such as investors, policy makers, and regulatory bodies, so that they can assess management's behavior in using IT...” (Joshi et al., 2013, p. 118). It should be noted that IT governance transparency can be about internal transparency (e.g. by making IT governance practices known on the firm's intranet), as well as external transparency. It is important to stress that this research deals with public voluntary disclosure about IT governance (i.e. with the goal of informing external stakeholders). The international enterprise governance and management of IT good-practice framework COBIT 5 also refers to the importance of ensuring stakeholder transparency in the context of IT governance. In its process reference model, COBIT 5 describes this process, EDM05 Ensure stakeholder transparency, as required to "...ensure that enterprise IT performance and conformance measurement and reporting are transparent, with stakeholders approving the goals and metrics and the necessary remedial actions..." (ISACA, 2012, p. 47).

As IT-related information disclosure is voluntary in nature, not every firm will engage in such disclosure practices. We posit that voluntary information dissemination on IT topics will be largely influenced by the IT capabilities of firms, which heavily rely on efficient IT governance (Zhang, Zhao, \& Kumar, 2016). To this end, the importance of IT governance transparency, or voluntary disclosure of IT governance-related information, can be explained using the resource-based theory. Drawing from this theory, IT can positively influence a firm's performance when the firm effectively uses IT to support and enhance its core competencies (Ravichandran \& Lertwongsatien, 2005). More specifically, the quality of IT business expertise and the extent to which there are positive relationships between business and IT managers significantly and positively influence the competitive advantage of the firm (Bhatt \& Grover, 2005). As IT governance is about ensuring that IT sustains and extends the organization's strategy and about aligning business and IT (De Haes \& Van Grembergen, 2015; IT Governance Institute (ITGI), 2003), we expect that IT governance will increase the competitive advantage of the firm. Actually, we expect this competitive advantage to be sustained. Mata, Fuerst, and Barney (1995) argue that, from a resource-based perspective, not IT capital requirements, proprietary technology or technical IT skills, but managerial IT skills will provide sustainability. Sustained competitive advantage can be achieved when a resource or capability is (1) valuable, (2) heterogeneously distributed across competing firms and (3) imperfectly mobile (Mata et al., 1995). Managerial IT skills meet these three requirements and IT governance does as well. IT governance is a valuable capability, as its ultimate goal is to increase business value from IT investments (De Haes \& Van Grembergen, 2015). It is heterogeneously distributed, as it is not developed to the same extent in every firm (Weill, 2004). Lastly, IT governance is imperfectly mobile, as implementing IT governance practices is challenging and requires careful design (De Haes \& Van Grembergen, 2015).

Hence, taking a resource-based view of the firm, IT governance is a capability that creates sustained competitive advantage. We expect that investors will react positively to the presence of such a capability. Indeed, Dehning, Richardson, and Zmud (2003) examined the effects of announcements of transformational information technology investments. They found that organizations announcing investments in IT projects that significantly change the way these organizations work, reap the benefits in the form of a positive, abnormal increase of the market value. The authors posited that the type of IT investment is of significant importance. Whereas most IT investments are related to short-term or uncertain profits, investors look for a sustained increase in earnings. Therefore, they seek IT investments that generate stable and continuous gains. Similarly, as IT governance meets the three criteria of sustained competitive advantage, it can lead to sustained profit generation. Therefore, we expect that investors recognize the value of IT governance and will react positively when organizations report on the implementation of IT governance practices, through the voluntarily disclosure of IT governance-related information. 


\subsection{IT Governance Disclosure Framework}

Joshi et al. (2013) present an IT governance disclosure framework based on the IT governance areas as defined by the IT governance institute (2003). Specifically, their IT governance disclosure framework contains 39 disclosure items distributed over the following domains: IT strategic alignment, IT value delivery, IT risk management, and IT performance measurement. 'IT strategic alignment' deals with the fact that IT investments need to support the strategic goals and objectives of an organization to enable the creation of current and future business value. 'IT value delivery' is concerned with the optimization of IT-enabled value creation, where value is broader than strictly monetary (e.g. competitive advantage, higher employee productivity, etc.). 'IT risk management' is concerned with the protection of IT-assets and recovery from IT-related disasters. Finally, 'IT performance measurement' is related to the IT budget and IT investments. It is specifically concerned with the expenditure on IT resources and its association to business value. For this research, the IT governance disclosure framework will serve as operationalization of the IT governance disclosure construct. The full disclosure framework, together with a description of each item (which improves the content or face validity of the contained items), is presented in Appendix A.

\subsection{Conceptual Model and Operationalization}

The underlying conceptual model for this research is presented in Figure 1. This representation is based on Libby's predictive validity framework (Libby, Bloomfield, \& Nelson, 2002), which

Figure 1. Conceptual model and operationalization
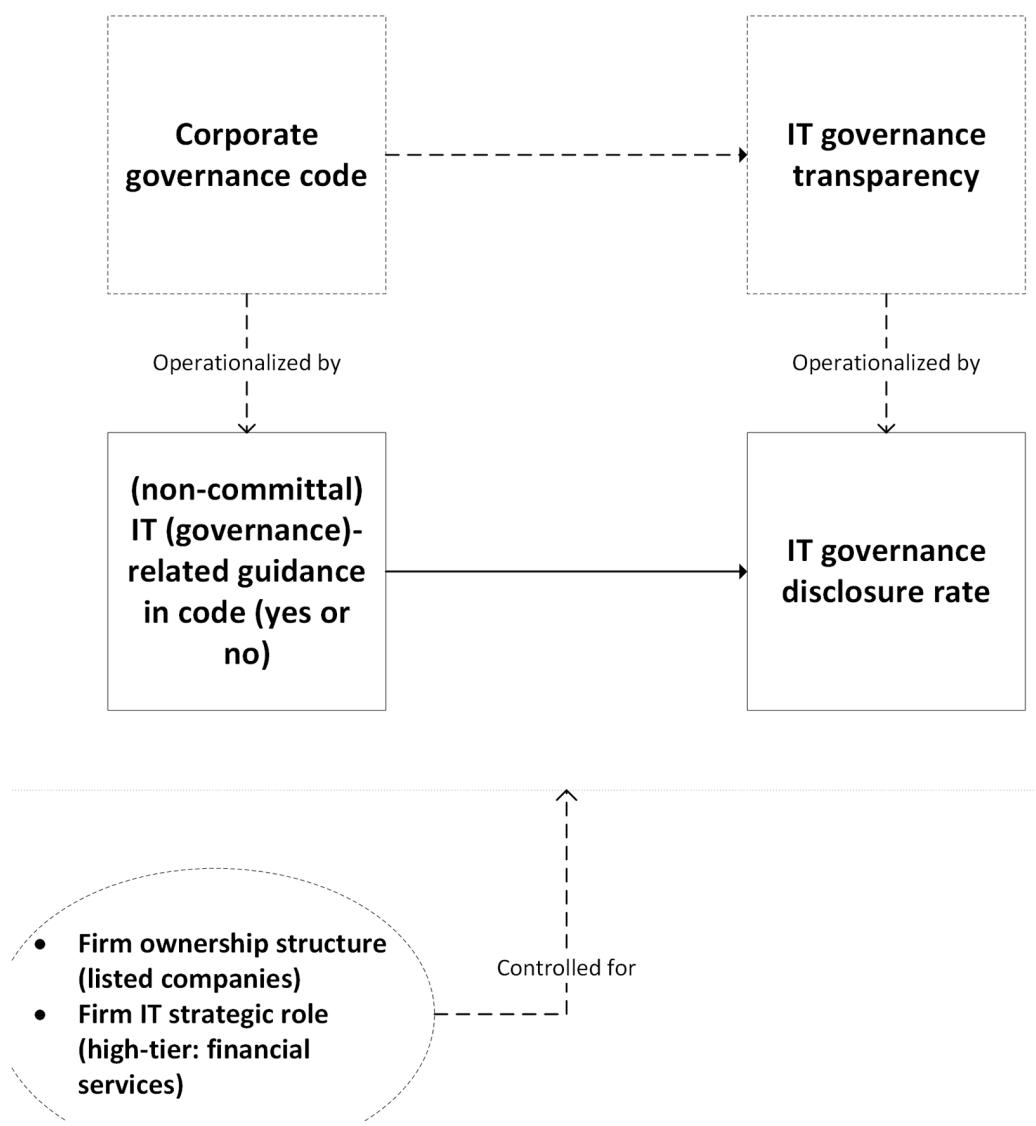
emphasizes the important role of careful conceptual specification of constructs in theory-based empirical research. The dashed boxes represent the conceptual level, while the boxes below represent the operationalization of the concepts used in this research. The concept of IT governance transparency will be operationalized using the IT governance disclosure rate derived from the IT governance transparency framework by Joshi et al. (2013). The concept of corporate governance code will be operationalized by means of Boolean categorization: either the code contains (non-committal) IT (governance)-related guidance or it does not. This is to enable the comparison of IT governance disclosure between two groups of interest, in line with our proposition. The purpose of the first research question is to enable the purposive selection of two groups of companies to answer the second research question, by determining which corporate governance codes contain IT (governance)-related guidance and to what extent. This purposive selection will be aimed at maximal variation: a group of firms subject to a corporate governance code that contains a significant amount of IT (governance)related guidance, and a group of firms subject to a corporate governance code that contains little to none IT (governance)-related guidance. These considerations will be discussed more in-depth in the 'research methodology'-section. While exploring the influence of the corporate governance code on IT governance transparency, this research controls for firm ownership structure and firm IT strategic role for internal validity considerations.

\section{RESEARCH APPROACH}

The research started with a literature review to ground the study and to define the main concepts used in the research project. For the empirical research stage, the followed approach for the first research question and the second research question (related with its proposition) are discussed in turn over the following sections.

\subsection{Analysis of Corporate Governance Codes for IT (Governance)-Related Guidance}

The selection of national corporate governance codes is based on maximal variation purposive sampling to improve the external validity (Suri, 2013). Two dimensions were specified to guide this sampling process: geographically (i.e. continent), and economically (i.e. income groups). For the geographical dimension, the traditional 7-continent model was employed: Africa, Asia, Europe, Australia, North America, South America, and Antarctica. The economic dimension is based on the income classification of the World Bank: low-income, lower-middle-income, upper-middle-income, high-income, and high-income OECD members. Countries are categorized by Gross National Income (GNI) per capita at nominal values, calculated by the World Bank using the 'World Bank Atlas method'. The GNI per capita is the dollar value of a country's final income in a year, divided by its population. It hence reflects the average income of a country's citizens. For this research, the classification of 2016 was used, which is based on the GNI data of 2015. To simplify the economic dimension, some of the World Bank's categories are merged to retain three income categories: low (consisting of lowincome and lower-middle-income), middle (consisting of upper-middle income), and high (consisting of high-income and high-income OECD members). Using these two dimensions, a matrix is created in which each cell represents countries with a certain income category and geographically located in a certain continent. Next, all countries were distributed over the cells using the World Bank's data ${ }^{1}$. Using an index of all corporate governance codes around the world ${ }^{2}$, a national corporate governance code was selected to populate as many cells as possible. When a country had multiple corporate governance codes, the most recent code for listed companies based upon which annual reports are available was selected. An additional requirement was that the corporate governance code should be available in English. The final sample of national corporate governance codes $(\mathrm{N}=15)$ is presented in Table 1. The ISO 3166-1 Alpha-2 codes are added in parentheses. 
Table 1. Final sample of national corporate governance codes by continent and income group ( $N=15$ )

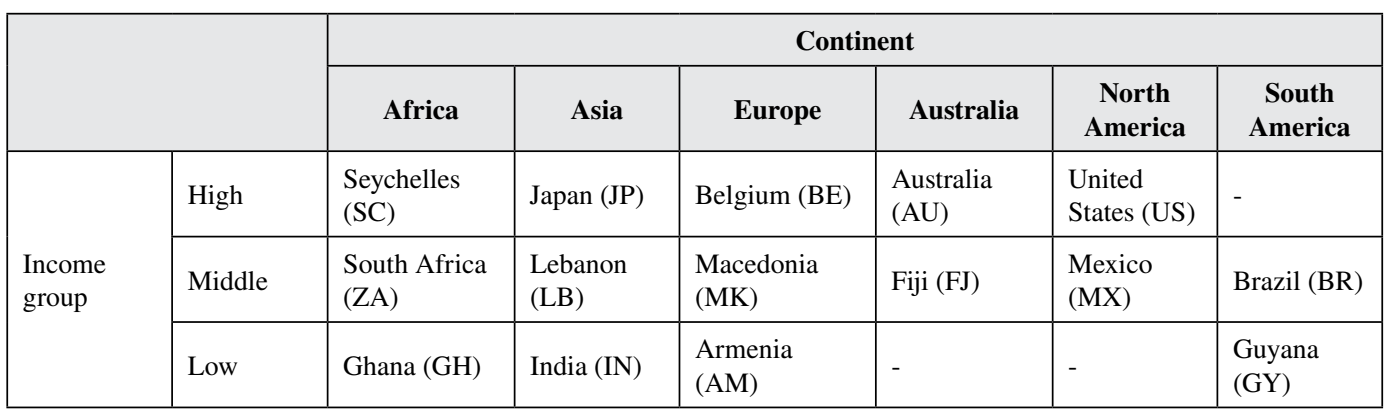

To analyze each corporate governance code for IT (governance)-related content, the IT governance transparency framework by Joshi et al. (2013) was used. If the IT (governance)-related content of the IT governance transparency framework is included as guidelines in the national corporate governance code, firms can be expected to comply with these guidelines or disclose on the specific reasons for not complying with a certain practice or guideline. Otherwise, there might be potential market consequences for these firms (i.e. market punishment in the form of lowered firm valuation) (MacNeil \& Li, 2006). The qualitative data analysis procedure that was used for analyzing the corporate governance codes is conceptual content analysis, also known as thematic analysis. This enables the analysis of the existence and frequencies of concepts of interest based on a coding frame (Schreier, 2012), and is therefore very suitable for our purpose. Using the IT governance transparency framework as a coding frame, a binary classification approach was used while analyzing the national corporate governance codes; i.e. an item is scored ' 1 ' if the item is present as a guideline or practice in the corporate governance code, and scored ' 0 ' otherwise. The code content analysis was completed by a single coder.

\subsection{The Influence of Corporate Governance Codes on IT Governance Transparency}

After analyzing a selection of 15 national corporate governance codes with respect to the included IT (governance)-related content, the extent to which the national corporate governance code influences the level of IT governance disclosure of a firm can now be examined. To improve the internal validity while answering the second research question, the research was scoped down to control for potential contingency factors. Specifically, we scoped down to financial services organizations to control for IT strategic role, and to listed companies to control for ownership structure. For controlling IT strategic role, we follow Sohal \& Fitzpatrick (2002), who discern between "high tier industries" and "low tier industries". High tier industries are characterized by the fact that IT is the most crucial factor to influence the core business of a company. Examples of such industries are banking, communications, and insurance. On the other hand, in low tier industries IT is generally used at an operational level only, to provide automated support of basic tasks. Examples of such industries are transportation, construction, manufacturing, and natural resources. Because of differences in IT strategic role between industries, there might also be differences in IT governance maturity (De Haes \& Van Grembergen, 2015), which could obscure the effect of the national corporate governance code (if any) on IT governance transparency. For controlling ownership structure, it was decided to only select listed companies, as the disclosure of non-financial information improves the value of a firm's stock, due to a reduction of information asymmetry (Healy \& Palepu, 2001). Hence, firms that are publicly listed can be expected to disclose more on their IT governance, as part of non-financial disclosure in general, compared to firms that are not publicly listed, as they have more incentive to do so. The focus on listed companies might therefore enable more interesting results. 
The sample for the second research question is a purposive sample of firms conform the scope. Specifically, two groups of ten firms are selected. This smaller sample size is due to our specific focus to improve the internal validity of the research. The first group consists of Belgian financial services firms that are listed on Euronext Brussels, while the second group consists of South African financial services firms that are listed on the Johannesburg Securities Exchange (JSE). The selection of these groups is in line with the specified research question and proposition, and is resulting from our results regarding the first research question (i.e. the South African corporate governance code King III $^{3}$ contains a significant amount of IT (governance)related guidance while the Belgian corporate governance code 2009 does not). The final sample $(\mathrm{N}=20)$ is presented in Table 2 .

For each firm in the sample the English annual report of 2014 was obtained and analyzed, as these were the most recent available at the time. The annual report is a public disclosure document that is available for all firms. Additionally, Joshi et al. (2013) found that the annual report seems to be the preferred medium for sharing information regarding IT governance. The analysis of the annual reports of 2014 for all firms implies a cross-sectional analysis. Similarly to the preceding step of analyzing the corporate governance codes for IT (governance)-related content, the qualitative data analysis procedure that was used is conceptual content analysis (or thematic analysis). This enables the analysis of the existence and frequencies of concepts of interest based on a coding frame (Schreier, 2012), and is therefore very suitable for answering the second research question. Applied to this research, IT governance disclosure items will be identified in the annual reports, using the IT governance disclosure framework as a coding frame. Each annual report is manually analyzed by a single coder, applying dichotomous coding for each disclosure item in the framework (i.e. a score of ' 1 ' if the item is present in the annual report and a score of ' 0 ' otherwise). Joshi et al. (2013) provide a definition for each disclosure item that was included in the disclosure framework (see Appendix A), hence improving the content or face validity of the items and as such supporting the objectivity of the coding process. For each category of the IT governance disclosure framework, an 'IT governance disclosure rate' can then be calculated as:

$$
\frac{1}{n} \sum_{i=1}^{n} x_{i}
$$

Table 2. Sample of Belgian and South African firms ( $\mathrm{N}=20)$

\begin{tabular}{|l|l|}
\hline \multicolumn{1}{|c|}{ Belgian Group } & \multicolumn{1}{c|}{ South African Group } \\
\hline Ageas & ABSA Bank Limited \\
\hline Ascencio & Alexander Forbes Group Holdings \\
\hline Befimmo & Clientele Limited \\
\hline Dexia & Discovery Holdings Limited \\
\hline GBL & Grindrod Bank \\
\hline Iep Invest & Liberty Holdings Limited \\
\hline KBC & MMI Holdings Limited \\
\hline Nationale Bank van België & Sanlam \\
\hline Sofina & Santam \\
\hline Solvac & Sasfin Bank \\
\hline
\end{tabular}




\section{RESULTS}

\subsection{Analysis of Corporate Governance Codes for IT (Governance)-Related Guidance}

Table 3 presents the item-level analysis of the 15 corporate governance codes for IT (governance)related content. A first general observation is that, aside from the South African code, the corporate governance codes score very low overall when it comes to including IT (governance)-related practices or guidelines. A reasonable explanation for this observation is that many national corporate governance codes are based on the OECD principles of corporate governance (OECD, 2015). Specifically, for our sample, 8 out of 15 national corporate governance codes explicitly state being based on the OECD principles. The remaining 7 corporate governance codes show a lot of similarities with the OECD principles, but they don't explicitly refer to OECD. As previously discussed, the G20/OECD principles do not include specific directives regarding IT governance or IT governance disclosure, aside from using the company website as a disclosure channel for material company information.

The South African corporate governance code, King III, contains a significant amount of IT (governance)-related guidance. King III came into effect for South African entities starting from 1 March 2010 and is applicable to all entities (i.e. regardless of their size and whether or not they are listed). King III contains a specific IT governance chapter consisting of seven IT governance principles and some additional and more detailed recommended practices for each of these principles (Institute of Directors in Southern Africa, 2009). When applying the IT governance disclosure framework, 8 out of 11 of the 'IT strategic alignment' items, 4 out of 13 'IT value delivery' items, and 5 out of 7 'IT risk management' items can be identified in the South African corporate governance code. Like all the other sampled corporate governance codes, King III does not contain any guidelines regarding the 'IT performance measurement' category. This can be explained by the fact that the items belonging to this financial category do not really belong in a corporate governance code. Rather, guidelines

Table 3. Item-level analysis of corporate governance codes for IT (governance)-related guidance

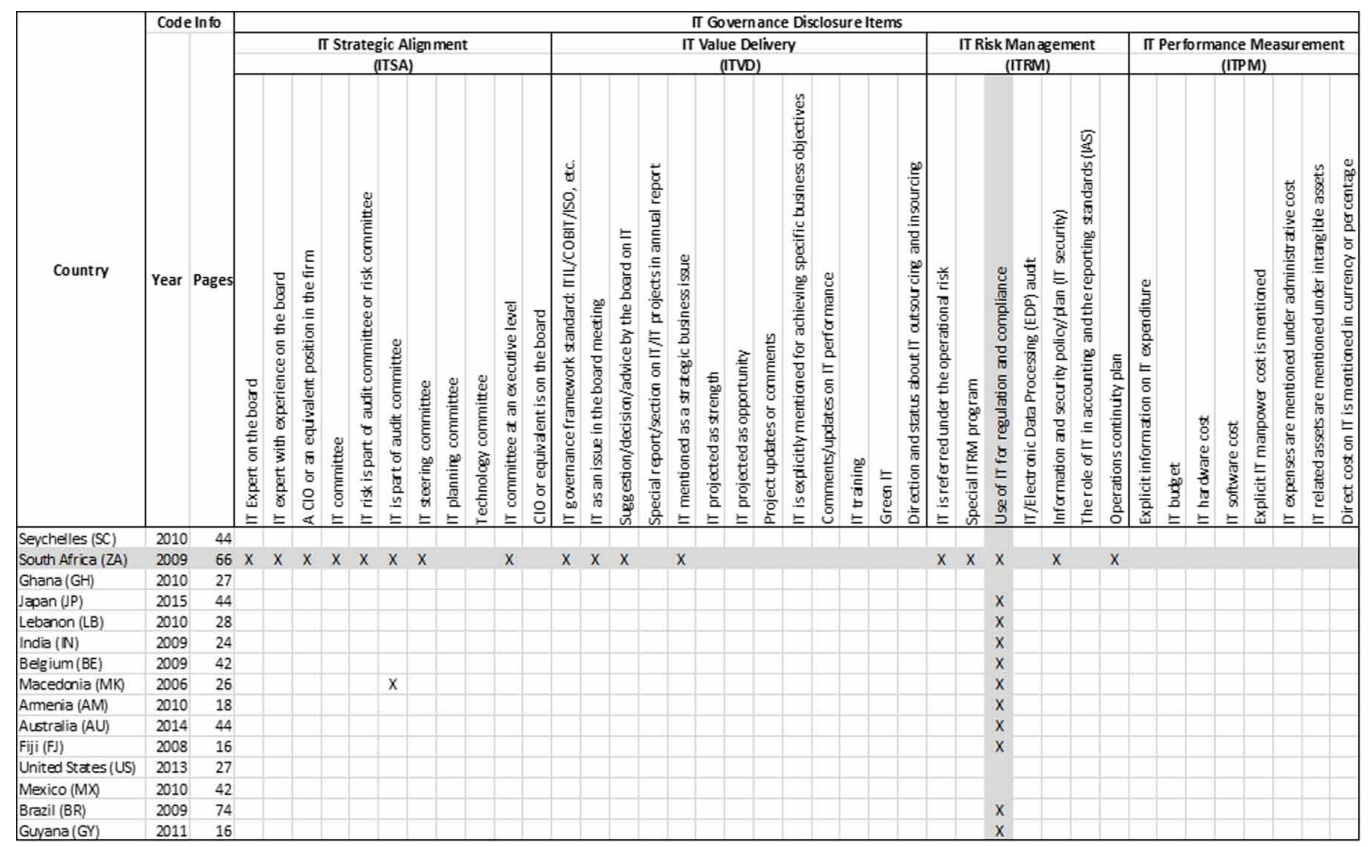


concerning these items belong in financial reporting standards. Indeed, hardware falls under IAS 16 regulation and software is put under intangible assets by IAS 38 regulation.

An interesting observation at the item-level is that 'Use of IT for regulation and compliance', belonging to the 'IT risk management' category is found in 11 out of 15 of the selected corporate governance codes. Again, a reasonable explanation can be found in the contents of the G20/OECD principles on corporate governance. As part of its 'disclosure and transparency' chapter, it is specifically stated that the company website provides an excellent way to disclose material company information (OECD, 2015). This is indeed a way of using IT for regulation and compliance. Finally, the item 'IT is part of audit committee', belonging to the 'IT strategic alignment' category, is also found in the Macedonian corporate governance code. These are the only two disclosure items that were found in other corporate governance codes besides King III.

Interestingly, several changes have been made to the IT governance content while transitioning from King III to King IV in its current form. King IV is now referring to "technology and information governance", thereby recognizing information separate from technology as a corporate asset and confirming the need for governance structures to protect and enhance this asset. The overarching principle regarding technology and information governance in King IV is that "The governing body should govern technology and information in a way that supports the organization in defining core purpose and to set and achieve strategic objectives."

We conclude this section by pointing out that the overlap of IT governance research and King III research is scarce. First, Butler \& Butler (2010) present a literature study where they map the IT governance content of King III to key focus areas of IT governance as defined by leading authors in the IT governance body of knowledge. They conclude that the King III IT governance content maps very well to these focus areas, indicating that when firms are applying the IT governance principles as contained in King III, they are applying IT governance practices that are conform the IT governance state-of-the-art. Additionally, the authors propose some IT governance structures/management roles to address the King III IT governance content. Second, Goosen \& Rudman (2013) develop guidance for effectively and efficiently addressing King III's IT governance principles and practices. These authors start from the King III practice that senior management has the responsibility to implement the IT governance framework, while acknowledging that they often lack the necessary capabilities to do so effectively. The research presented in the following section (i.e. to investigate the influence of the IT (governance)-related content of the King III code on South African firm's IT governance transparency as opposed to firms that are subject to a corporate governance code that does not contain a significant amount of IT (governance)-related guidance) is therefore a unique contribution to this overlapping research area.

\subsection{The Influence of Corporate Governance Codes on IT Governance Transparency}

In order to provide an answer to the second research question (and the proposition that was derived from this research question), an analysis was performed between financial services organizations that are listed on Euronext Brussels (and therefore subject to the Belgian corporate governance code 2009 - a corporate governance code that contains almost no IT (governance)-related guidance), and financial services organizations that are listed on the Johannesburg Securities Exchange (and therefore subject to the South African code King III - a corporate governance code that contains a significant amount of IT (governance)-related guidance). The results of this analysis are first overviewed at the level of the disclosure categories in Table 4. The group with the highest average disclosure rate for each disclosure category is bold-faced.

This first global overview of IT governance transparency between both groups shows that the listed South African financial services organizations seem to be more concerned with disclosing on their IT governance than the listed Belgian financial services organizations. This observation holds for all disclosure categories of the IT governance transparency framework. This result could be expected, as King III contains a significant amount of (non-committal) IT (governance)-related 
Table 4. Reporting rate per disclosure category

\begin{tabular}{|l|l|l|l|}
\hline & \multicolumn{1}{|c|}{$\begin{array}{c}\text { Belgian Companies } \\
(\mathbf{N = 1 0})\end{array}$} & $\begin{array}{c}\text { South African Companies } \\
(\mathbf{N = 1 0})\end{array}$ & \multicolumn{1}{|c|}{ Full Sample (N=20) } \\
\hline IT strategic alignment & $8 \%$ & $\mathbf{2 5 \%}$ & $16.5 \%$ \\
\hline IT value delivery & $6 \%$ & $\mathbf{3 8} \%$ & $22 \%$ \\
\hline IT risk management & $21 \%$ & $\mathbf{3 3} \%$ & $27 \%$ \\
\hline $\begin{array}{l}\text { IT performance } \\
\text { measurement }\end{array}$ & $16 \%$ & $\mathbf{2 9} \%$ & $22.5 \%$ \\
\hline Average & $12.75 \%$ & $\mathbf{3 1 . 2 5} \%$ & $22 \%$ \\
\hline
\end{tabular}

guidance while the Belgian corporate governance code does not. More specifically, the key concepts of the IT (governance)-related guidance incorporated in King III are highly correlated with the five IT governance focus areas upon which the IT governance disclosure framework was based. We conclude that our empirical research points at some evidence for the justification of the proposition that was derived from the second research question. Table 5 also globally indicates that there are potential opportunities for the firms in our sample to improve on their IT governance transparency. While this is true for both groups, it is especially true for the Belgian firms.

Next, we investigate the IT governance disclosure at item-level, which enables some deeper discussion. These results are displayed in Table 5.

The group with the highest disclosure rate for each item is bold-faced (both groups in the case of a draw). In line with the previous discussion about the results per disclosure category, the South African companies show higher reporting rates on almost all of the individual items.

\subsubsection{IT Strategic Alignment}

With an average of $16.5 \%$ over the whole sample $(\mathrm{N}=20)$, 'strategic alignment' is the least reported upon among the four disclosure categories of the IT governance transparency framework. This is a surprising result for two reasons. First, IT governance is the responsibility of the board (De Haes \& Van Grembergen, 2015) and the majority of the items in the IT strategic alignment category are specifically situated at the board level (e.g. 'IT expert on the board', 'IT expert with experience on the board', 'CIO or equivalent is on the board', 'IT committee' etc.). Second, IT strategic alignment is the category that is represented most exhaustively in King III, with 8 out of 11 category items being included in the South African corporate governance code. Hence, we would expect to frequently find these items in South African annual reports.

However, strategic alignment is often perceived as a very complex challenge, to the point where decision makers are unsure about how to approach the alignment challenge (Preston $\&$ Karahanna, 2009). Furthermore, while academic literature indicates that a high degree of board involvement in IT governance, and IT experience at the board, has a positive effect on organizational performance (Bart \& Turel, 2010; Nolan \& McFarlan, 2005; Turel \& Bart, 2014), Nolan \& McFarlan (2005) state that boards are often not aware of the importance of IT when it comes to supporting corporate objectives and the need for alignment between the overall corporate strategy and the IT strategy. Additionally, the board is often incapable to ask IT management "the right questions" due to a lack of expertise, leading to the inability to effectively monitor the management of IT (Bart \& Turel, 2010). It should also be noted that putting the CIO (or equivalent) on the board, putting an IT expert at the board, or putting an IT committee in place at the level of the board, can help in solving these issues (De Haes \& Van Grembergen, 2009). This seems to be an opportunity for the organizations in the sample, as for instance only one South African firm explicitly reports having a CIO or equivalent on the board, and only three South African firms report on having a board-level IT committee. None of the Belgian 
Table 5. Item-level reporting rates

\begin{tabular}{|c|c|c|}
\hline IT Strategic Alignment Items & $\mathrm{BE}(\mathrm{N}=10)$ & $\mathrm{SA}(\mathbf{N}=10)$ \\
\hline IT expert on the board & $1 / 10$ & $2 / 10$ \\
\hline IT expert with experience on the board & 0 & $2 / 10$ \\
\hline A CIO or an equivalent position in the firm & $3 / 10$ & $5 / 10$ \\
\hline IT committee & 0 & $3 / 10$ \\
\hline IT risk is part of audit committee or risk committee & $3 / 10$ & $6 / 10$ \\
\hline IT is part of audit committee & $1 / 10$ & $4 / 10$ \\
\hline IT steering committee & 0 & $3 / 10$ \\
\hline IT planning committee & $\mathbf{0}$ & 0 \\
\hline Technology committee & 0 & $1 / 10$ \\
\hline IT committee at an executive level & $1 / 10$ & $1 / 10$ \\
\hline $\mathrm{CIO}$ or equivalent is on the board & 0 & $1 / 10$ \\
\hline Reporting rate (average) & $8 \%$ & $25 \%$ \\
\hline IT value delivery items & $\mathrm{BE}(\mathrm{N}=10)$ & $\mathbf{S A}(\mathbf{N}=10)$ \\
\hline IT governance framework/standard: ITIL/COBIT/ISO etc. & 0 & $9 / 10$ \\
\hline IT as an issue in the board meeting & 0 & $6 / 10$ \\
\hline Suggestion/decision/advise by the board on IT & 0 & $1 / 10$ \\
\hline Special report/section on IT/IT projects in annual report & $1 / 10$ & $8 / 10$ \\
\hline IT mentioned as a strategic business issue & $3 / 10$ & $7 / 10$ \\
\hline IT projected as strength & 0 & $3 / 10$ \\
\hline IT projected as opportunity & 0 & $2 / 10$ \\
\hline Project updates or comments & $2 / 10$ & $3 / 10$ \\
\hline IT is explicitly mentioned for achieving specific business objectives & $1 / 10$ & $3 / 10$ \\
\hline Comments/updates on IT performance & $1 / 10$ & $2 / 10$ \\
\hline IT training & 0 & $4 / 10$ \\
\hline Green IT & $\mathbf{1} / \mathbf{1 0}$ & 0 \\
\hline Direction and status about IT outsourcing and in-sourcing & 0 & $1 / 10$ \\
\hline Reporting rate (average) & $6 \%$ & $38 \%$ \\
\hline IT risk management items & $\mathrm{BE}(\mathrm{N}=10)$ & $\mathrm{SA}(\mathbf{N}=\mathbf{1 0})$ \\
\hline IT is referred under the operational risk & $6 / 10$ & $5 / 10$ \\
\hline Special IT risk management program & $3 / 10$ & $2 / 10$ \\
\hline Use of IT for regulation and compliance & 0 & $5 / 10$ \\
\hline IT/electronic data processing (EDP) audit & 0 & $2 / 10$ \\
\hline Information and security policy/plan (IT security) & $2 / 10$ & $5 / 10$ \\
\hline The role of IT in accounting and the reporting standards (IAS) & $2 / 10$ & $2 / 10$ \\
\hline Operations continuity plan & $2 / 10$ & $2 / 10$ \\
\hline Reporting rate (average) & $21 \%$ & $33 \%$ \\
\hline
\end{tabular}




\begin{tabular}{|l|l|l|}
\hline \multicolumn{1}{|c|}{ IT performance measurement items } & BE $(\mathbf{N}=10)$ & \multicolumn{1}{c|}{ SA (N=10) } \\
\hline Explicit information on IT expenditure & $\mathbf{0}$ & $\mathbf{4 / 1 0}$ \\
\hline IT budget & $\mathbf{0}$ & $\mathbf{0}$ \\
\hline IT hardware cost & $\mathbf{4 / 1 0}$ & $\mathbf{4 / 1 0}$ \\
\hline IT software cost & $\mathbf{6 / 1 0}$ & $\mathbf{7 / 1 0}$ \\
\hline Explicit IT manpower cost is mentioned & $\mathbf{0}$ & $\mathbf{0}$ \\
\hline IT expenses are mentioned under administrative cost & $\mathbf{0}$ & $\mathbf{1 / 1 0}$ \\
\hline IT related assets are mentioned under intangible assets & $\mathbf{3 / 1 0}$ & $\mathbf{7 / 1 0}$ \\
\hline Direct cost on IT is mentioned in currency or percentage & $\mathbf{0}$ & $\mathbf{0}$ \\
\hline Reporting rate (average) & $\mathbf{1 6 \%}$ & $\mathbf{2 9 \%}$ \\
\hline
\end{tabular}

firms report on these two items. The previous discussion is entirely in line with principle 5.1 of King III, i.e. "the board should be responsible for IT governance", clearly pointing at the need for board involvement in IT governance. The issue of strategic alignment is articulated in principle 5.2 of King III, i.e. "IT should be aligned with the performance and sustainability objectives of the company".

As increasing the involvement of the board of directors in IT governance appears to be a challenge, South African companies might need more time to implement and report on this element of the in King III suggested guidance. Indeed, the annual reports of 2014 were examined, while King III was introduced in 2009. Thus, this study indicates how much of the King III guidance was implemented by these organizations over a five-year span. In this regard, a study by Coertze and von Solms (2013) analyzing board level IT governance pre and post King III shows promising results. They found that the level of board member IT experience, board-level CIO presence and the presence board-level IT oversight committees all increased after the introduction of King III, respectively with $20 \%, 5 \%$ and $40 \%$.

When the $\mathrm{CIO}$ (or equivalent) is not on the board, the firm can still have such a position. Practice 5.3.3 of King III states that "the CEO should appoint a CIO responsible for the management of IT". Remarkably, only half of the firms in the South African sample report on the existence of a CIO position (or equivalent) at the firm. The importance of a CIO position has also been the subject of academic research. Chatterjee, Richardson, \& Zmud (2001) found that investors tend to reward the announcement of a new CIO position in organizations that are operating in an industry that is subject to IT-enabled transformation (like financial services). The CIO appointment enables confidence in the capability of the firm to effectively manage its IT assets. While it is not explicitly articulated in King III that the CIO should be on the board, King III's recommended practice 5.3.4 states that “... the CIO should be a suitably qualified and experienced person who should have access and interact regularly on strategic IT matters with the board and/or appropriate board committee and executive management". Indeed, Discovery Holdings Limited declares that "the Board has appointed a Group Chief Information Officer whom they believe is suitable, qualified, and experienced and who reports to the Board on all IT-related matters..." Various CIO arrangements can be found in the selected annual reports. While Discovery Holdings Limited's board appointed the CIO and included him as a board member, at Liberty Holdings Limited the CIO was selected by the CEO and MMI Holdings Limited appointed a Chief Technology Officer (CTO) who reports to the Chief Operating Officer (COO).

Strategic alignment items 'IT risk is part of audit committee or risk committee' and 'IT is part of audit committee' can be linked to King III's principle 5.7 “A risk committee and audit committee should assist the board in carrying out its IT responsibilities." This might explain why these items are reported upon more frequently by the South African firms in the sample. At MMI Holdings 
Limited for example, IT governance issues are handled by the Risk and Compliance Committee, while the Audit Committee deals with financial reporting risks, IFC, and fraud and information technology risks as these relate to financial reporting. The item 'IT risk is part of audit committee or risk committee' is, together with the presence of the CIO or equivalent position, the most reported item for Belgian firms as well. An explanation can be found in the Belgian corporate governance code, which it identifies "monitoring of the financial reporting process" (in which IT is crucial) and "monitoring of the effectiveness of systems for risk management" as tasks of the audit committee (Commissie Corporate Governance, 2009), which both clearly relate to IT. Strategic alignment item 'IT steering committee' is addressed in recommended practice 5.3.2 of King III: "The board may appoint an IT steering committee or similar function to assist with its governance of IT." Only 3 out of 10 South African firms report on having such an IT steering committee (as opposed to 0 Belgian firms), which might be due to the very careful formulation of this recommended practice (i.e. 'may' instead of 'should').

\subsubsection{IT Value Delivery}

For the IT value delivery category, the difference of the average reporting rate between Belgian and South African firms is largest. For the Belgian firms, it is the category which is with $6 \%$ least reported upon, while for the South African firms it is the category which is with $38 \%$ most frequently reported upon. When it comes to IT value delivery in general, King III's recommended practice 5.4.1 explicitly states that "...the board should oversee the value delivery of IT and monitor the return on investment from significant IT projects...," which provides an explanation for the difference in IT value delivery disclosure rate between the two countries. Academic research has already identified the importance of disclosing about IT investments. Investors tend to reward disclosure about IT investments when they expect that these investments will have a positive effect on current and future business value (Dehning, Richardson, \& Zmud, 2003; Im, Dow, \& Grover, 2001).

Yet, the overall reporting rate of the IT value delivery is rather low, certainly for Belgian firms. A possible explanation could be the protection by organizations of their competitive advantage. That is, as explained in the previous section, IT governance can be seen as a capability leading to sustained competitive advantage. However, this sustained competitive advantage is based on three characteristics: IT governance is (1) valuable, (2) heterogeneously distributed across competing firms and (3) imperfectly mobile. On the one hand all IT value delivery items relate to the first characteristic, explaining how IT is used to deliver business value and how this value delivery is optimized. On the other hand, reporting on those items might reverse the second characteristic. Hence, organizations might be reluctant to report on IT value delivery as they fear competitors might copy their value delivery practices and by doing so weakening their competitive advantage.

There are a few items in the IT value delivery category that are very dominant in establishing the difference in average disclosure rate between the Belgian and South African firms, which all seem to be related to King III principles. First, 'IT governance framework/standard' is reported upon by 9 out of 10 South African firms as opposed to 0 Belgian firms. This can potentially be attributed to King III's principle 5.3, which specifically mentions that an IT governance framework should be implemented by management. Most firms simply report on the existence and goal of such a framework, like Alexander Forbes Group Holdings, that reports “...the IT governance framework supports effective and efficient management and decision making around the utilisation of IT resources to facilitate the achievement of the Group's objectives and the management of IT-related risk." Discovery Holdings Limited explains into detail what is covered in their IT governance framework. This explanation is shown in Figure 2. Second, 'IT as an issue in the board meetings' is reported upon by 6 out of 10 South African firms as opposed to 0 Belgian firms. Once more, this can be linked to King III's principle 5.1 in general, and recommended practice 5.1.1 in specific: "The board should assume the responsibility for the governance of IT and place it on the board agenda." Clientèle Limited literally mention that "...the Board and Group Audit Committee have formally accepted the overall responsibility for IT 


\begin{abstract}
"A formal IT governance framework consisting of various policies, standards, and guidelines has been approved and implemented within the Group. This framework is fundamental to the operations of Discovery and covers:

- The implementation of a dedicated Information and Data Security function to ensure that an appropriate Information Security Programme is implemented within the business.

- The establishment of a formal process to oversee and manage all IT investments and capital expenditure.

- The establishment of a number of operational and strategic IT committees to ensure that the Group infrastructure appropriately supports business objectives and strategy.

- The implementation of a Business Continuity Framework to ensure that appropriate plans and controls are in place to ensure that all aspects of business resilience and disaster recovery are adequately dealt with."
\end{abstract}

and it has been formally assigned to the Board. IT governance is an item on the Board agenda." Third, the item 'special report/section on IT/IT projects in annual report' was found in 8 out of 10 South African firms as opposed to 1 out of 10 Belgian firms. As King III contains a chapter dedicated to IT governance, addressing several principles and recommended practices, it makes sense for firms to cluster these issues in their annual reports. As previously discussed, the Belgian corporate governance code 2009 does not contain such a specific IT (governance)-related chapter or section. It is therefore our belief that including a specific section on IT-related matters in the annual report enables firms to think about ways to disclose on their IT governance and IT management arrangements, thereby increasing their overall IT governance transparency. Indeed, South African firms appear to be guided in this direction because of the contents of King III.

The item 'IT mentioned as a strategic business issue' is reported by 7 out of 10 South African firms. In its introduction, King III specifically states that “....not only is IT an operational enabler for a company, it is an important strategic asset to create opportunities and gain competitive advantage..." This statement, and the fact that IT has such a prominent role in the corporate governance code, might trigger South African companies to report on IT as a strategic business issue. While this is the IT value delivery item that Belgian firms report most on, it is included in only 3 out of 10 Belgian annual reports. Grindrod Bank states that "IT is considered fundamental to the support and sustainability of Grindrod's business operations - both as an operational enabler and a strategic asset that can be leveraged to create opportunities and mitigate risks". Nevertheless, in a recent ITGI survey (2011), $94 \%$ of the respondents explicitly stated that IT is important to achieve strategic business goals. It is therefore surprising that the related item 'IT is explicitly mentioned for achieving specific business objectives' is only reported in 4 out of 20 annual reports. KBC for example reports on the creation of a new online application to get closer to their customers. A more specific example is given by Alexander Forbes Group Holdings, they mention “...two new systems came online to support the collection, reporting and evidencing of management information related to treating customers fairly (TCF). These allow us to produce TCF-enabled management reports that will assist us to manage, report and evidence our TCF progress." Giving concrete examples of how a firm is using IT for achieving specific business goals can therefore be seen as an opportunity for firms to include in their annual reports. The item 'Green IT' is mentioned in only one of the annual reports. This is surprising, as corporate social responsibility and sustainability became hot topics. In 2011, 20\% of the respondents in an ITGI survey indicated that their firms were planning for green IT initiatives (IT Governance Institute (ITGI), 2011). Fujitsu indicated that “...emissions from IT are projected to increase from $3 \%$ 
of total global emissions in 2009 to a whopping 6\% by 2020..." (Fujitsu, 2010). Sustainability is also an important part of King III, seen as King III requires firms to disclose on their CSR performance as well as ensure the independent assurance of CSR-related disclosure (Ackers, 2015). However, it seems that firms are reporting on other sustainability aspects rather than IT-related sustainability. Indeed, IT-related sustainability is not explicitly mentioned in the King III report. Additionally, academic research did not find a significant correlation between CSR reporting and share prices in the South African context (Marcia, Callaghan, \& Maroun, 2015), possibly indicating that firms might not see value in CSR reporting. Finally, only 1 out of 20 firms report on 'IT outsourcing and insourcing'. Nevertheless, $73 \%$ of respondents of an ITGI survey indicated that some IT activities were fully outsourced in their companies, $20 \%$ of respondents partially outsourced some IT activities and only 5\% of respondents did not outsource anything IT-related (IT Governance Institute (ITGI), 2011). A possible explanation for the low reporting rate regarding IT outsourcing could be that organizations are often rather careful or even suspicious when it comes to the outsourcing of their IT activities (Derksen, 2013). If the organizations also suspect such suspicion among (potential) investors, it makes sense from their point of view to not explicitly report on this item.

\subsubsection{IT Risk Management}

The IT risk management category is with $21 \%$ the most frequently reported upon category for the Belgian firms in the sample, while still trailing behind the South African firms in average disclosure rate. For the South African firms, IT risk management is with $33 \%$ the second most reported upon of the four disclosure categories. The focus on IT risk management by Belgian firms could be induced by the Belgian corporate governance code. According to the code, a firm's corporate governance charter should include "... a description of the main features of the company's internal control and risk management systems..." As organizations highly depend on IT (De Haes \& Van Grembergen, 2015), which is particularly true for the financial services sector (Sohal \& Fitzpatrick, 2002), IT-related risks constitute an important concern. Indeed, KBC states in its annual report that “...we consider cyber risk, including hacking, to be one of the most important risks. In a world that is becoming increasingly digital, cyberattacks are a constant threat, with possibly important financial and reputational damage." Evidently, the importance of IT-related risks also applies to South African firms. Another explanation for the high reporting rates on risk management is the importance of IT risk management in IT governance implementation. That is, the global status report on the governance of enterprise IT of the IT Governance Institute (ITGI) (2011) shows that the improvement of IT-related risk management is the most commonly experienced outcome of implementing IT governance practices. King III also contains specific principles and recommended practices for IT risk management and IT security. Principle 5.5 is 'IT should form an integral part of the company's risk management'. Additionally, King III's recommended practice 5.7.2 states that "The risk committee should obtain appropriate assurance that controls are in place and effective in addressing IT risks..." It is therefore somewhat surprising that IT risk management item 'special IT risk management program' is only mentioned in 2 out of 10 annual reports of South African financial services organizations. South African firms report considerably more on 'use of IT for regulation and compliance', which is somewhat related to King III's recommended practice 5.5.2: “...the board should ensure that the company complies with IT laws and that IT related rules, codes and standards are considered..." South African firms also appear to be more concerned with reporting on IT security compared to Belgian firms. King III's recommended practices belonging to principle 5.6 are especially related to this disclosure item: 5.6.1 "...the board should ensure that there are systems in place for the management of information which should include information security, information management and information privacy...;" 5.6.2 "....the board should ensure that all personal information is treated by the company as an important business asset and is identified...," 5.6.3 "...the board should ensure that an information security management system is developed and implemented...;" and 5.6.4 "...the board should approve the information security strategy and delegate and empower management to implement the strategy..." 
Despite these IT security-related recommended practices in King III, we find only half of the South African firms in the sample to be reporting on this IT security item. This is especially noteworthy as we are dealing strictly with financial services organizations, a sector which is known to be dealing with substantial amounts of confidential data, making IT security a necessity. Academic research also indicates the need for IT security. For instance, Campbell, Gordon, Loeb, \& Zhou (2003) found that a security breach, leading to unauthorized access to confidential data has a negative impact of about 5\% on the value of a firm's stock. Gordon, Loeb, \& Sohail (2010) found a positive correlation between the voluntary disclosure about information security and the market value of a company. Indeed, some firms report on their security measures rather in detail. Alexander Forbes Group Holdings states: “...our Protection of Personal Information (POPI) governance structure is fully functioning. We have performed a high-level risk assessment and are in the process of gathering data to perform a more detailed analysis across the group. This will inform the drafting and implementation of more detailed plans. In the meantime, we have begun to implement immediate actions in order to comply with POPI in time. These include education and awareness, a clean desk policy, encryption, legal opinions, procurement objectives, building security actions, mobile device management and revised customer and third-party documentation." Clientele Limited keeps it short, but accentuates the responsibility of the board, reporting that "...the board ensures that the information and intellectual property contained in the information systems are protected..." The Belgian firms show a remarkably high reporting rate for referring to IT under the operational risk. The National Bank of Belgium for example states that IT security is one of the five work groups created to structure operational risk management. This high reporting rate is probably an effect of the high dependence on IT in today's digital world (De Haes \& Van Grembergen, 2015).

Even though research indicates that IT risk management is clearly an investor concern, the IT risk management reporting rate is rather low. Yet, a substantial part of the annual reports in the sample is attributed to risk management. A possible explanation is the fact that IT risk management is not addressed separately from general business and operational risk. Indeed, in the European Banking Authority risk assessment of the European banking system report of June 2014, it is shown that two thirds of the respondents indicated that they cover IT risks as part of their general operational risk management (European Banking Authority (EBA), 2014b). This finding might be reflected in the 2014 annual reports. However, a trend towards a more targeted risk management approach was identified. In the following report of the European Banking Authority, 58\% of respondents indicated an enhancement of their IT governance and risk culture and $42 \%$ enhanced business continuity plans while only $21 \%$ covered IT risks under a general operational risk (European Banking Authority (EBA), 2014a). Hence, we might find more IT risk management items in annual reports of the following years.

\subsubsection{IT Performance Measurement}

The IT performance measurement category shows no significant differences in reporting rates between Belgian and South African firms. There are three dominant categories in this group: 'IT software cost'; 'IT related assets are mentioned under intangible assets'; and 'IT hardware cost', which appears to be true for the Belgian firms as well as the South African firms. King III does not contain any directives in its principles and recommended practices relating to IT performance measurement. Nevertheless, a possible explanation for the dominance of these items can be found in financial reporting regulation. Listed companies need to report their consolidated annual reports following the International Accounting Standards (IAS). IAS 38 puts software under intangible assets. Unsurprisingly, most Belgian and South African firms in our sample specifically mention software cost and place it under intangible assets in their financial statements. Belgian and South African firms tend to report on hardware cost as well in their financial statements, which falls under IAS 16 regulation. In the previous discussion on the IT (governance)-related content of corporate governance codes it was already pointed out that these financial-related practices are not really part of the scope of a corporate governance code. Hence, the low overall reporting rate can be mainly attributed to the 
remaining items, which are not incorporated in financial reporting regulation, pointing to a reluctance by organizations to voluntarily report on IT performance measurement. A probable reason is that it is simply extremely difficult to estimate IT-related costs $(\mathrm{Oz}, 2005)$.

'Explicit information on IT expenditure' is more reported by South African firms than Belgian firms. The former firms disclose this specific item in 4 out of 10 cases, while this is true for none of the Belgian firms. Alexander Forbes Group Holdings states it “...uses both in-house and third-party developed IT systems and has made continuous investments to remain up to date with regulatory changes and clients' evolving requirements. In 2013/14, we invested R127 million in strengthening our systems." This might be seen in the overall realm of more IT governance transparency for the South African firms: when most annual reports contain a specific section with attention for IT-related matters, it also makes sense to provide more detail on IT-related expenses in the financial statements. This is therefore a clear opportunity for the Belgian firms in the sample to be more transparent about. In the practitioner area, IT managers report that IT expenditure is a critical attention point for them (ITGI, 2011, Global Status Report on the Governance of Enterprise IT (GEIT); ITGI, 2011, Global Status Report on the Governance of Enterprise IT (GEIT); ITGI, 2011, Global Status Report on the Governance of Enterprise IT (GEIT)). According to the IT Governance Institute (2011) survey results, $45.3 \%$ of the respondents were planning initiatives to reduce IT expenditure. Also, $38.7 \%$ of the respondents indicated that the increasing IT expenditure was perceived as a problem. Considering this, it is strange that none of the annual reports contains information about the IT budget, as this is clearly a related issue. The estimation of IT-related costs is notoriously difficult $(\mathrm{Oz}, 2005)$. As firms have difficulties in estimating the IT budget, they might also be reluctant to reporting these figures in their annual reports. Another plausible reason for the absence of IT budget in the annual reports might be that firms are attempting to reduce proprietary costs.

\section{CONCLUSION AND IMPLICATIONS}

\subsection{Conclusions}

This paper put forward two objectives. First, a selection of national corporate governance codes was analyzed with respect to IT (governance)-related content. Second, the influence of the national corporate governance code on a firm's IT governance transparency was explored. Answering the first research question, we observed that only the South African corporate governance code, King III, contains a significant amount of IT (governance)-related guidance. Building on these findings, the contemporary state of IT governance transparency in Belgian and South African companies was then compared to meet the second research objective. The proposition was that there could be potential variations in a firm's IT governance disclosure due to variations in IT (governance)-related content in national corporate governance codes. Using an established IT governance transparency framework, we found that the South African firms in our sample seemed to be more concerned with IT governance transparency than the Belgium firms in our sample, given a comparable ownership structure and IT strategic role (i.e. listed financial services organizations). This observation holds for all disclosure categories of the IT governance transparency framework.

This study provides two key contributions to the current literature on IT governance transparency. First, we provide an empirical assessment on how corporate governance codes at national level can shape up the mechanisms of IT governance. To this end, our finding shows that the current governance codes have very minimal inclusion of IT governance topics. As a result, this calls for broader insights to understand how corporate governance embeds and foster various mechanisms of IT governance, especially IT governance transparency. Second, comparing Belgian and South African firms while keeping the industry constant, we examine the level of IT governance disclosure in annual reports. This way, we indirectly assess whether a higher emphasis on IT related topics in corporate governance code can stimulate a higher level of IT governance disclosure. The results suggest that the level of IT 
governance disclosure in annual reports is positively correlated to the institutional setting in which IT governance is a key topic in the corporate governance code.

There are still major potential opportunities for the firms in our sample to improve on their IT governance transparency. While this is true for both groups, it is especially true for the Belgian firms, as this group is trailing behind the South African group for all categories of the disclosure framework. Subsequent analysis at the item-level also indicates that many of the items on which South African firms tend to report frequently can be directly related to the IT governance principles and recommended practices contained in the King III corporate governance code. We therefore conclude that the higher IT governance transparency of the South African firms might very well be attributed to the contents of their national corporate governance code.

The results show that the overall IT governance disclosure rate is rather low. We found that the main reason is twofold. First, a low reporting rate might imply a low implementation rate. Items relating to for instance board level IT governance are less well represented in annual reports as board engagement in IT governance is lacking in many organizations (Andriole, 2009; Bart \& Turel, 2010; Coertze \& von Solms, 2014). Second, it seems that organizations do not yet fully recognize the value of IT governance disclosure. Yet, IT governance might lead to sustained competitive advantage, which is highly valued by investors, suggesting the importance of IT governance disclosure. On the other hand, the fact that IT governance might lead to sustained competitive advantage could provide an explanation for the low amount of IT governance disclosure. That is, for a resource or capability to lead to competitive advantage, it should be heterogeneously distributed across competing firms. In this view, it might be plausible that firms consider IT governance competencies could be mimicked, and therefore deliberately hold in IT-related information from competitors. As a result, the level of IT governance disclosure in public documents might be lower.

\subsection{Implications}

From an academic point of view, this research adds to the relatively unexplored domain of IT governance transparency. Specifically, this research adds to the empirical backbone of IT governance transparency as a research subject in general, and the IT governance disclosure framework in specific. This research extends prior empirical research regarding IT governance disclosure by investigating the influence of the national corporate governance code on IT governance transparency. Using the Joshi et al. (2013) IT governance disclosure framework, we were able to collect some preliminary empirical evidence in support of the indicated proposition.

From a practitioners' stance, we believe that this exploratory research illustrates the need for including IT governance-related directives in national corporate governance codes. As IT becomes more pervasive in firms all over the world, it makes sense for firms to be transparent about these, often very important, IT-related matters; and for national corporate governance codes to guide firms in such a direction. From the standard setting perspective, the study provides preliminary evidence on the need of the inclusion of IT governance topics in corporate governance codes. Specifically, it warrants further attention of policy makers on the topic of IT governance while developing and implementing corporate governance codes. This study also helps to explore the fundamental role of corporate governance principles in shaping IT governance practices at firm level by providing evidence that the presence of IT-related principles in corporate governance codes can encourage firms in disseminating IT governance information in public documents. The importance of IT governance transparency should also be stressed outside the national corporate governance code. In its current edition, the international good-practice framework COBIT 5 already refers to the importance of ensuring stakeholder transparency in the context of IT governance. However, this discussion remains rather high-level and abstract. Practitioners would certainly benefit from more specific guidelines regarding IT governance transparency as part of the COBIT framework. 


\section{LIMITATIONS AND OPPORTUNITIES FOR FUTURE RESEARCH}

In this last section, the limitations of this research are discussed and related opportunities for future work are proposed. First, this research only deals with disclosed information. There could very well be discrepancies between what is reported and what is implemented regarding IT governance. For instance, an organization may have a dedicated CIO function, but it is possible that this is not explicitly mentioned in their annual report. It would therefore be very interesting to link this study with IT governance maturity to detect discrepancies between the IT governance implementation in organizations and their disclosure. Second, this study deals with a relatively small sample size of firms $(\mathrm{N}=20)$. This was motivated by a strong focus on the internal validity of the research and an in-depth discussion of the issues, but it stands without question that a large-sample study would be interesting. If the sample size is large enough, statistically significant differences in the proportions could be tested for using z-tests, which in turn would increase the reliability of the results. Another opportunity for future research is data triangulation. This study only used annual reports as a data source. This was motivated by the fact that annual reports seem to be the preferred medium for IT governance-related disclosure. Nevertheless, data triangulation using additional data sources (e.g. press releases, company website, etc.) would enable a richer understanding of a firm's IT governance disclosure. Third, the coding of IT governance information from the corporate governance codes was performed by a single coder. This might potentially impose certain limitations on the reliability of the coding. However, the coder has coded information using an established IT governance disclosure framework (Appendix A). The framework provides concrete descriptions for each of the items, thereby providing face validity. Therefore, we assume that the usage of a single coder will have minimal or even negligible impact of the reliability of the coded information. Finally, the IT governance transparency framework by Joshi et al. (2013) was employed to analyze the IT (governance)-related contents of the national corporate governance codes in our sample $(\mathrm{N}=15)$. However, this framework is not specifically built for this application. Nevertheless, it is the only validated IT governance transparency framework in literature that could be employed as a coding frame to gauge the extent of IT (governance)-related content in national corporate governance codes. This limitation boils down to the remark that further research is required to develop recommendations for national corporate governance codes to include IT (governance)-related guidance, which will in turn increase the IT governance transparency of firms that are using these corporate governance codes as a guiding framework for their annual reports. 


\section{REFERENCES}

Ackers, B. (2015). Ethical considerations of corporate social responsibility-a South African perspective. South African Journal of Business Management, 46(1), 11-21. doi:10.4102/sajbm.v46i1.79

Ailon, G. (2011). Mapping the cultural grammar of reflexivity: The case of the Enron scandal. Economy and Society, 40(1), 141-166. doi:10.1080/03085147.2011.529331

Andriole, S. (2009). Boards of Directors and Technology Governance: The Surprising State of the Practice. Communications of the Association for Information Systems, 24, 22.

Augustine, D. (2012). Good Practice in Corporate Governance: Transparency, Trust, and Performance in the Microfinance Industry. Business \& Society, 51(4), 659-676. doi:10.1177/0007650312448623

Bart, C., \& Turel, O. (2010). IT and the Board of Directors: An Empirical Investigation into the "Governance Questions" Canadian Board Members Ask about IT. Journal of Information Systems, 24(2), 147-172. doi:10.2308/ jis.2010.24.2.147

Bhatt, G. D., \& Grover, V. (2005). Types of Information Technology Capabilities and Their Role in Competitive Advantage: An Empirical Study. Journal of Management Information Systems, 22(2), 253-277. doi:10.1080/ 07421222.2005.11045844

Butler, R., \& Butler, M. J. (2010). Beyond King III : Assigning accountability for IT governance in South African enterprises. South African Journal of Business Management, 41(3), 33-45.

Campbell, K., Gordon, L. A., Loeb, M. P., \& Zhou, L. (2003). The economic cost of publicly announced information security breaches: Empirical evidence from the stock market. Journal of Computer Security, 11(3), 431-448. doi:10.3233/JCS-2003-11308

Chatterjee, D., Richardson, V. J., \& Zmud, R. W. (2001). Examining the Shareholder Wealth Effects of Announcements of Newly Created CIO Positions. Management Information Systems Quarterly, 25(1), 43-70. doi: $10.2307 / 3250958$

Coertze, J., \& von Solms, R. (2013). The Board and IT Governance: A Replicative Study. African Journal of Business Management, 7(35), 3358-3373. doi:10.5897/AJBM2013.7172

Coertze, J., \& von Solms, R. (2014). The Board and CIO: The IT Alignment Challenge. In 2014 47th Hawaii International Conference on System Sciences (pp. 4426-4435).

Commissie Corporate Governance. (2009). Belgische Corporate Governance Code 2009. Retrieved from http:// www.corporategovernancecommittee.be/sites/default/files/generated/files/page/corporategovnlcode2009.pdf

Damianides, M. (2005). Sarbanes-Oxley and it Governance: New Guidance on it Control and Compliance. Information Systems Management, 22(1), 77-85. doi:10.1201/1078/44912.22.1.20051201/85741.9

De Haes, S., \& Van Grembergen, W. (2009). An Exploratory Study into IT Governance Implementations and its Impact on Business/IT Alignment. Information Systems Management, 26(2), 123-137. doi:10.1080/10580530902794786

De Haes, S., \& Van Grembergen, W. (2015). Enterprise governance of information technology (2nd ed.). Springer. doi:10.1007/978-3-319-14547-1

Dehning, B., Richardson, V. J., \& Zmud, R. W. (2003). The value relevance of announcements of transformational information technology investments. Management Information Systems Quarterly, 27(4), 637-656. doi: $10.2307 / 30036551$

Derksen, B. (2013). Impact of IT Outsourcing on Business \& IT Alignment. University of Amsterdam.

Eisenhardt, K. M. (1989). Agency Theory: An Assessment and Review. Academy of Management Review, 14(1), 57-74. doi:10.5465/amr.1989.4279003

European Banking Authority (EBA). (2014a, December). Risk Assessment of the European Banking System. Retrieved from http://www.eba.europa.eu/documents/10180/934862/EBA+2014.6941+RAR+web. $\mathrm{pdf} / 7 \mathrm{~d} 2 \mathrm{~d} 629 \mathrm{a}-\mathrm{b} 212-4 \mathrm{~b} 1 \mathrm{a}-96 \mathrm{c} 2-62 \mathrm{db} 832 \mathrm{ea} 03 \mathrm{c}$ 
European Banking Authority (EBA). (2014b, June). Risk Assessment of the European Banking System. Retrieved from https://www.eba.europa.eu/documents/10180/556730/EBA+Risk+Assessment+Report+June+2014.pdf/ b2f43a31-1319-478f-9502-a03633d6efe7

Fujitsu. (2010). Green IT: The Global Benchmark. Retrieved from http://www.ictliteracy.info/rf.pdf/green_IT_ global_benchmark.pdf

Goergen, M. (2012). International Corporate Governance. Prentice Hall.

Goosen, R., \& Rudman, R. (2013). The development of an integrated framework in order to address King Ill's IT governance principles at a strategic level. South African Journal of Business Management, 44(4), 91-103. doi:10.4102/sajbm.v44i4.171

Gordon, L., Loeb, M., \& Sohail, T. (2010). Market Value of Voluntary Disclosures Concerning Information Security. Management Information Systems Quarterly, 34(3), 567-594. doi:10.2307/25750692

Healy, P. M., \& Palepu, K. G. (2001). Information asymmetry, corporate disclosure, and the capital markets: A review of the empirical disclosure literature. Journal of Accounting and Economics, 31(1-3), 405-440. doi:10.1016/S0165-4101(01)00018-0

Heart, T., Maoz, H., \& Pliskin, N. (2010). From Governance to Adaptability: The Mediating Effect of IT Executives' Managerial Capabilities. Information Systems Management, 27(1), 42-60. doi:10.1080/10580530903455163

Huang, R., Zmud, R. W., \& Price, R. L. (2010). Influencing the effectiveness of IT governance practices through steering committees and communication policies. European Journal of Information Systems, 19(3), 288-302. doi:10.1057/ejis.2010.16

Im, K. S., Dow, K. E., \& Grover, V. (2001). Research Report: A Reexamination of IT Investment and the Market Value of the Firm—An Event Study Methodology. Information Systems Research, 12(1), 103-117. doi:10.1287/ isre.12.1.103.9718

Institute of Directors in Southern Africa. (2009). King III Code of Corporate Governance for South Africa. Retrieved from https://jutalaw.co.za/uploads/King_III_Report/

ISACA. (2012). COBIT 5: Enabling Processes. Retrieved from http://www.isaca.org/COBIT/Pages/COBIT-5Enabling-Processes-product-page.aspx

IT Governance Institute (ITGI). (2003). Board Briefing on IT Governance (2nd ed.). Retrieved from http:// www.isaca.org/knowledge-center/research/researchdeliverables/pages/board-briefing-on-it-governance-2ndedition.aspx

IT Governance Institute (ITGI). (2011). Global Status Report on the Governance of Enterprise IT (GEIT). Retrieved from http://www.isaca.org/knowledge-center/research/researchdeliverables/pages/itgi-global-surveyresults.aspx

Joshi, A., Bollen, L., \& Hassink, H. (2013). An Empirical Assessment of IT Governance Transparency: Evidence from Commercial Banking. Information Systems Management, 30(2), 116-136. doi:10.1080/10580530.2013. 773805

Libby, R., Bloomfield, R., \& Nelson, M. W. (2002). Experimental research in financial accounting. Accounting, Organizations and Society, 27(8), 775-810. doi:10.1016/S0361-3682(01)00011-3

Lin, T. (2011). The Corporate Governance of Iconic Executives. Retrieved from http://scholarship.law.ufl.edu/ facultypub/121

MacNeil, I., \& Li, X. (2006). "Comply or Explain": Market discipline and non-compliance with the Combined Code. Corporate Governance, 14(5), 486-496. doi:10.1111/j.1467-8683.2006.00524.x

Mähring, M. (2006). The Role of the Board of Directors in IT Governance: A Review and Agenda for Research. In AMCIS 2006 Proceedings (p. 377).

Marcia, A., Callaghan, C., \& Maroun, W. (2015). Value relevance and corporate responsibility reporting in the South African context: An alternate view post King-III. South African Journal of Economic and Management Sciences, 18(4), 500-518. doi:10.4102/sajems.v18i4.1192 
Mata, F. J., Fuerst, W. L., \& Barney, J. B. (1995). Information Technology and Sustained Competitive Advantage: A Resource-Based Analysis. Management Information Systems Quarterly, 19(4), 487. doi:10.2307/249630

Millar, C. C., Eldomiaty, T. I., Choi, C. J., \& Hilton, B. (2005). Corporate Governance and Institutional Transparency in Emerging Markets. Journal of Business Ethics, 59(1-2), 163-174. doi:10.1007/s10551-005$3412-1$

Morris, R. D., Pham, T., \& Gray, S. J. (2011). The Value Relevance of Transparency and Corporate Governance in Malaysia Before and After the Asian Financial Crisis. Abacus, 47(2), 205-233. doi:10.1111/j.14676281.2011.00339.x

Nolan, R., \& McFarlan, F. (2005). Information technology and the board of directors. Harvard Business Review, 83(10), 96-106. PMID:16250628

OECD. (2015). G20/OECD Principles of Corporate Governance. Retrieved from http://www.oecd-ilibrary.org/ governance/g20-oecd-principles-of-corporate-governance-2015_9789264236882-en

Oz, E. (2005). Information technology productivity: In search of a definite observation. Information \& Management, 42(6), 789-798. doi:10.1016/j.im.2004.08.003

Peterson, R. R. (2004). Crafting Information Technology Governance. Information Systems Management, 21(4), 7-22. doi:10.1201/1078/44705.21.4.20040901/84183.2

Prasad, A., Green, P., \& Heales, J. (2012). On IT governance structures and their effectiveness in collaborative organizational structures. International Journal of Accounting Information Systems, 13(3), 199-220. doi:10.1016/j.accinf.2012.06.005

Preston, D. S., \& Karahanna, E. (2009). Antecedents of IS Strategic Alignment: A Nomological Network. Information Systems Research, 20(2), 159-179. doi:10.1287/isre.1070.0159

Raghupathi, W. (2007). Corporate Governance of IT: A Framework For Development. Communications of the ACM, 50(8), 94-99. doi:10.1145/1278201.1278212

Ravichandran, T., Lertwongsatien, C., \& Lertwongsatien, C. (2005). Effect of Information Systems Resources and Capabilities on Firm Performance: A Resource-Based Perspective. Journal of Management Information Systems, 21(4), 237-276. doi:10.1080/07421222.2005.11045820

Schreier, M. (2012). Qualitative content analysis in practice. Sage (Atlanta, Ga.).

Shailer, G. (2004). An Introduction to Corporate Governance in Australia. Pearson Education Australia.

Sohal, A. S., \& Fitzpatrick, P. (2002). IT governance and management in large Australian organisations. International Journal of Production Economics, 75(1-2), 97-112. doi:10.1016/S0925-5273(01)00184-0

Suri, H. (2013). Purposeful Sampling in Qualitative Research Synthesis. Qualitative Research Journal, 11(2), 63-75. doi:10.3316/QRJ1102063

Turel, O., \& Bart, C. (2014). Board-level IT governance and organizational performance. European Journal of Information Systems, 23(2), 223-239. doi:10.1057/ejis.2012.61

Uhlaner, L., Wright, M., \& Huse, M. (2007). Private Firms and Corporate Governance: An Integrated Economic and Management Perspective. Small Business Economics, 29(3), 225-241. doi:10.1007/s11187-006-9032-z

Van Grembergen, W., \& De Haes, S. (2009). Enterprise Governance of Information Technology: Achieving Strategic Alignment and Value. Springer.

Weill, P. (2004). Don't Just Lead, Govern: How Top-Performing Firms Govern IT. MIS Quarterly Executive, $3(1), 1-17$.

Weill, P., \& Ross, J. W. (2004). IT Governance: How Top Performers Manage IT Decision Rights for Superior Results. Harvard Business Press.

Zhang, P., Zhao, K., \& Kumar, R. L. (2016). Impact of IT Governance and IT Capability on Firm Performance. Information Systems Management, 33(4), 357-373. doi:10.1080/10580530.2016.1220218 


\section{ENDNOTES}

http://data.worldbank.org/about/country-and-lending-groups

http://www.ecgi.org/codes/all_codes.php

It should be noted that the South African corporate governance code was recently updated. The successor of King III, King IV, was released on 1 November 2016 and applied for financial years commencing from 1 April 2017 onwards. As at the time of writing no annual reports were available yet adhering to King IV, this research is based on King III. 


\section{APPENDIX A}

Table 6. IT governance disclosure framework by Joshi et al. (2013)

\begin{tabular}{|c|c|}
\hline & Description \\
\hline \multicolumn{2}{|l|}{ IT Strategic Alignment Items } \\
\hline IT expert on the board & $\begin{array}{l}\text { One or more board of directors who is/are independent or non-independent with } \\
\text { sufficient knowledge regarding IT and information assets. }\end{array}$ \\
\hline $\begin{array}{l}\text { IT expert with experience on the } \\
\text { board }\end{array}$ & $\begin{array}{l}\text { One or more board of directors who is/are with sufficient knowledge as well as } \\
\text { work experience with regard to IT and information assets. }\end{array}$ \\
\hline $\begin{array}{l}\text { A CIO or an equivalent position in } \\
\text { the firm }\end{array}$ & $\begin{array}{l}\text { Firm has a special CIO or an equivalent position with respect to IT and } \\
\text { information assets at an executive level. }\end{array}$ \\
\hline IT committee & A committee looking after IT and information assets at the board level. \\
\hline $\begin{array}{l}\text { IT risk is part of audit committee or } \\
\text { risk committee }\end{array}$ & $\begin{array}{l}\text { IT and information assets related risk are on the agenda of the Audit or Risk } \\
\text { committee. }\end{array}$ \\
\hline IT is part of audit committee & $\begin{array}{l}\text { IT and information assets auditing is part of the audit committee at the board } \\
\text { level. }\end{array}$ \\
\hline IT steering committee & $\begin{array}{l}\text { Firm has an IT steering committee which monitors IT management, IT } \\
\text { spending, and related cost allocations. }\end{array}$ \\
\hline IT planning committee & $\begin{array}{l}\text { Firm has an IT planning committee which looks after strategic planning and } \\
\text { investment decisions on IT and information assets. }\end{array}$ \\
\hline Technology committee & $\begin{array}{l}\text { A special committee which looks after IT and related technology architecture, } \\
\text { projects, and governance issue at an executive level. }\end{array}$ \\
\hline IT committee at an executive level & $\begin{array}{l}\text { In some countries there is a two-tier structure of corporate governance, in this } \\
\text { situation an IT committee may be formed at an executive level. This committee } \\
\text { reports to the supervisory board. }\end{array}$ \\
\hline CIO or equivalent is on the board & A CIO or an equivalent position is represented at the board level committee. \\
\hline \multicolumn{2}{|l|}{ IT value delivery items } \\
\hline $\begin{array}{l}\text { IT governance framework/standard: } \\
\text { ITIL/COBIT/ISO etc. }\end{array}$ & $\begin{array}{l}\text { These are best practices and frameworks for IT governance. The firm has } \\
\text { adopted or mentioned to adopt any IT governance framework. }\end{array}$ \\
\hline IT as an issue in the board meeting & $\begin{array}{l}\text { IT and information assets issues are explicitly discussed at the various board } \\
\text { level meeting. }\end{array}$ \\
\hline $\begin{array}{l}\text { Suggestion/decision/advise by the } \\
\text { board on IT }\end{array}$ & IT and related technology decisions, suggestions at the board level. \\
\hline $\begin{array}{l}\text { Special report/section on IT/IT } \\
\text { projects in annual report }\end{array}$ & $\begin{array}{l}\text { A special report or a section dedicated to provide information about IT and } \\
\text { information assets. }\end{array}$ \\
\hline $\begin{array}{l}\text { IT mentioned as a strategic business } \\
\text { issue }\end{array}$ & $\begin{array}{l}\text { IT is mentioned as a strategic business issue to accomplish the business mission } \\
\text { and goals. }\end{array}$ \\
\hline IT projected as strength & $\begin{array}{l}\text { IT and information assets are mentioned as the organizational strength to } \\
\text { achieve the business objectives, goals etc. }\end{array}$ \\
\hline IT projected as opportunity & $\begin{array}{l}\text { IT and information assets are referred as the key assets to achieve the future } \\
\text { opportunities. }\end{array}$ \\
\hline Project updates or comments & $\begin{array}{l}\text { Updates or comment about on-going and/or finished (successfully or } \\
\text { unsuccessfully) IT and related projects. }\end{array}$ \\
\hline $\begin{array}{l}\text { IT is explicitly mentioned for } \\
\text { achieving specific business } \\
\text { objectives }\end{array}$ & IT has been deployed to achieve one or more specific business objective. \\
\hline
\end{tabular}


Table 6. Continued

\begin{tabular}{|c|c|}
\hline & Description \\
\hline $\begin{array}{l}\text { Comments/updates on IT } \\
\text { performance }\end{array}$ & There is/are comments about good or bad performance of IT. \\
\hline IT training & Information on IT and related training program for human resource. \\
\hline Green IT & $\begin{array}{l}\text { Efficient and environment friendly use of is termed as Green IT. A firm has } \\
\text { reported on such initiative. }\end{array}$ \\
\hline $\begin{array}{l}\text { Direction and status about IT } \\
\text { outsourcing and in-sourcing }\end{array}$ & Information regarding in-sourcing or out-sourcing of IT. \\
\hline \multicolumn{2}{|l|}{ IT risk management items } \\
\hline $\begin{array}{l}\text { IT is referred under the operational } \\
\text { risk }\end{array}$ & $\begin{array}{l}\text { IT is considered as a potential risk to successful business functioning and being } \\
\text { treated as an operational risk. }\end{array}$ \\
\hline Special IT risk management program & Firm has a special program to mitigate IT and related technology risks. \\
\hline $\begin{array}{l}\text { Use of IT for regulation and } \\
\text { compliance }\end{array}$ & $\begin{array}{l}\text { IT is used to address the regulations and compliance requirements by the legal } \\
\text { institutions. }\end{array}$ \\
\hline $\begin{array}{l}\text { IT/electronic data processing (EDP) } \\
\text { audit }\end{array}$ & Firm has explicitly reported with regard to IT audit. \\
\hline $\begin{array}{l}\text { Information and security policy/plan } \\
\text { (IT security) }\end{array}$ & $\begin{array}{l}\text { Firm has a clear information and security policy for its stakeholders (e.g. } \\
\text { customers, employee). }\end{array}$ \\
\hline $\begin{array}{l}\text { The role of IT in accounting and the } \\
\text { reporting standards (IAS) }\end{array}$ & IT support for the accounting and to address certain framework (e.g. Basel II). \\
\hline Operations continuity plan & IT and related technology continuity plans are mentioned in case of disaster. \\
\hline \multicolumn{2}{|l|}{ IT performance measurement items } \\
\hline $\begin{array}{l}\text { Explicit information on IT } \\
\text { expenditure }\end{array}$ & $\begin{array}{l}\text { Financial and Non-financial statements containing information on the overall IT } \\
\text { expenditure. }\end{array}$ \\
\hline IT budget & $\begin{array}{l}\text { Financial section of the document has disclosed the budget on IT and } \\
\text { information assets. }\end{array}$ \\
\hline IT hardware cost & Specific IT hardware cost is mentioned under the IT expenditure. \\
\hline IT software cost & Specific IT software cost is mentioned under the IT expenditure. \\
\hline $\begin{array}{l}\text { Explicit IT manpower cost is } \\
\text { mentioned }\end{array}$ & Specific IT man power cost is mentioned under the IT expenditure. \\
\hline $\begin{array}{l}\text { IT expenses are mentioned under } \\
\text { administrative cost }\end{array}$ & $\begin{array}{l}\text { IT and information assets related expenses are mentioned under the } \\
\text { administrative cost. }\end{array}$ \\
\hline $\begin{array}{l}\text { IT related assets are mentioned under } \\
\text { intangible assets }\end{array}$ & $\begin{array}{l}\text { IT and related asset are referred as intangible assets and financial are provided } \\
\text { as intangible assets. }\end{array}$ \\
\hline $\begin{array}{l}\text { Direct cost on IT is mentioned in } \\
\text { currency or percentage }\end{array}$ & $\begin{array}{l}\text { The information on IT spending is given in the percentage of the total revenue } \\
\text { or in other accounting ratio. }\end{array}$ \\
\hline
\end{tabular}


Steven De Haes is a full professor of information systems management at the University of Antwerp-Faculty of Applied Economics and at the Antwerp Management School (Belgium). He is actively engaged in teaching and applied research in the domains of digital strategies; IT governance and management; IT strategy and alignment; IT value and performance management; IT assurance and audit; and information risk and security. He acts as the academic director for this research program.

Tim Huygh is a Ph.D. candidate in information technology governance at the department of management information systems of the faculty of applied economics, at the university of Antwerp. His research interests include IT governance and management, digital strategies, and business/IT alignment. His research was presented at ICIS and HICSS, and published in Information Systems Management and the International Journal of IT/Business Alignment and Governance (IJITBAG).

Anant Joshi is an assistant professor at Maastricht University (The Netherlands) and a visiting researcher at the University of Antwerp and Antwerp Management School (Belgium). His research interests include corporate governance of IT, business value of IT and corporate governance.

Laura Caluwe is a Ph.D. student at the University of Antwerp, Faculty of Applied Economics, Department of Management Information Systems. Her research area is IT governance with a specific focus on board-level issues. 